\title{
UK provision for removal of non-palpable contraceptive implants
}

\section{Diana Mansour}

\section{Introduction}

Over the last 2 years this Journal has seen a flurry of papers and resulting correspondence related to 'deep' Implanon ${ }^{\circledR}$ insertion. ${ }^{1-7}$ More than 3 million women use etonogestrel contraceptive implants worldwide and 180000 implants are fitted in the UK each year, with these numbers escalating as I write. From post-marketing data the reported rate of complex removal problems is low, running at about 1 per 1000 insertions. However, for a woman suffering nuisance side effects or wanting to become pregnant, this situation is frustrating and, for some, completely intolerable.

What improvements have been achieved to date in contraceptive implant provision? A number of meetings have been held with worldwide contraceptive implant 'experts'. Discussions have focused on the anatomical site for fitting contraceptive implants, the complications associated with insertion, and techniques for removal of deep and often 'non-palpable' implants. Dissemination of these discussions has taken place ${ }^{5,6}$ and the manufacturing company agreed to alter the insertion site instructions, bringing them more in line with the levonorgestrel multirod implants, Norplant ${ }^{\circledR}$ and Jadelle ${ }^{\circledR}$. The Summary of Product Characteristics (SPC) for Implanon now reads: ${ }^{8}$ "To minimise risk of neural or vascular damage, Implanon should be inserted at the inner side of the non-dominant upper arm about 8-10 cm above the medial epicondyle of the humerus".

It is surprising that some senior clinicians have misinterpreted this information and have either thought Implanon should be inserted on the under surface of the arm or over the triceps. There has also been concern that some health care professionals are no longer fitting Implanon as they are confused about these new instructions. Very little has changed. The insertion site can now be moved out of the sulcus between the biceps and triceps ("Tiger Country" for 'deep implant removers') ${ }^{9}$ and many choose to insert it subdermally over the biceps on the anterior side of the non-dominant arm. ${ }^{10}$ Those who wish to insert Implanon in the sulcus may continue to do so as the SPC advice does not contraindicate this.

\section{Specialist centres for implant removal}

Whose responsibility is it to provide a regional referral service for the removal of deep, 'non-palpable' contraceptive implants? With the publication of the National Institute for Health and Clinical Effectiveness guideline covering long-acting reversible contraceptives (LARCs) ${ }^{11}$ and the roll-out of local LARC initiatives countrywide encouraging increasing use of contraceptive implants, Strategic Health Authorities (SHAs), Health

J Fam Plann Reprod Health Care 2009; 35(1): 3-4

Newcastle Contraception and Sexual Health Services, Newcastle General Hospital, Newcastle upon Tyne, UK Diana Mansour, FRCOG, FFSRH, Consultant in Community Gynaecology and Reproductive Health Care

Correspondence to: Dr Diana Mansour, Newcastle Contraception and Sexual Health Services, Graingerville Clinic, Newcastle General Hospital, Newcastle upon Tyne NE4 6BE, UK. E-mail: diana.mansour@newcastle-pct.nhs.uk
Boards and health care commissioners must support and release funding to establish regional services for location and removal of deep contraceptive implants. The onus should not be placed at the doors of the pharmaceutical industry to manage a clinical complication resulting from incorrect insertion.

A number of UK regional referral sites have been established to locate and remove deep, impalpable contraceptive implants (Table 1). These centres all have an ultrasound machine to localise implants, and have some experience of removing deeply placed implants. For those interested in providing this service there have been some important lessons learnt by many of the 'expert' removers.

First, a business plan should be submitted to those holding the purse strings and a service level agreement with additional funding agreed. This is particularly important for women who are referred from neighbouring SHA regions. It is also important that all the 'expert' centres now develop appropriate pathways to deal with those deeply placed implants that they cannot remove.

Second, it must be remembered that most 'deep' implants result from poor insertion technique by health care professionals. Women referred to 'specialist' centres are frequently unhappy with their care and may have waited significant lengths of time to be seen. If possible the location and removal should take place on the same day, especially if women have travelled long distances. Ideally there need to be two trained health care professionals who can remove 'deep' implants in the service to cover annual, study and sick leave. Careful documentation of all referred cases is essential as occasionally these are subject of a complaint or litigation. The health care professional who inserted the non-palpable implant should be informed and, if there are repeated events, the lead clinician within the primary care organisation or hospital should be contacted to ensure that no further implants are inserted by this person until supervised retraining has taken place. Women with non-palpable implants are an 'adverse event' and should be reported via the local risk management process and anonymously to Organon Laboratories, part of the Schering-Plough Corporation.

To maintain surgical skills the health care professional should remove at least 12 'deep' implants each year (one a month). Consequently there is little point setting up a service - with significant upfront costs for surgical and ultrasound equipment - if few women will be seen.

\section{Conclusions}

Organon Laboratories have been most responsible in supporting contraceptive implant theoretical and practical training. They have also supported the development of the referral centres through education and training. It is now time for the company to allow the National Health Service to realise its responsibilities. In England the Department of Health has allocated $£ 26.8$ million of additional money to local primary care organisations and SHAs to improve access to contraception. ${ }^{12}$ Those holding that money should use it wisely and appropriately, making sure that their population has quality contraceptive provision including referral pathways for 'expert' help. Unfortunately, at the time of writing this article, this primary care organisation allocation is still a 'well-kept 
Table 1 Referral sites in the UK for removal of deep/non-palpable contraceptive implants2

\begin{tabular}{|c|c|}
\hline Name of contact & Address \\
\hline $\begin{array}{l}\text { Dr Gillian Flett } \\
\text { Dr Kate Weaver } \\
\text { Dr Audrey Brown } \\
\text { Dr Diana Mansour } \\
\text { Dr Sandra McDermott } \\
\text { Dr Kate Guthrie } \\
\text { Dr Babatunde Gbolade } \\
\text { Dr Steve Chadwick } \\
\text { Dr Nathan Acladious } \\
\text { Dr Suzanne Kirkwood } \\
\text { Dr Stephen Searle } \\
\text { Dr Emeka Oloto } \\
\text { Dr Kulsum Jaffer } \\
\text { Dr Mike Newman } \\
\text { Dr Jo Hoddinott } \\
\text { Dr Terry McCarthy } \\
\text { Dr Sharon Bodard } \\
\text { Dr Lynsey Dunkley } \\
\text { Dr Liz Tanner } \\
\text { Dr Tina Peers } \\
\text { Dr Liz Azzopardi } \\
\text { Dr Jane Dickson } \\
\text { Dr Katherine Creamer } \\
\text { Dr Kate Paterson } \\
\text { Dr Chris Wilkinson } \\
\text { Dr May Erskine }\end{array}$ & $\begin{array}{l}13 \text { Golden Square, Aberdeen AB10 } 1 \text { RH } \\
18 \text { Dean Terrace, Edinburgh EH4 } 1 \text { NL } \\
\text { Sandyford Initiative, 2-6 Sandyford Place, Glasgow G3 7NB } \\
\text { Graingerville Clinic, Newcastle General Hospital, Westgate Road, Newcastle upon Tyne NE4 6BE } \\
\text { Brae Clinic, Waterside Health and Social Care Centre, 127-147 Spencer Road, Londonderry BT47 6AQ } \\
\text { Conifer House, 32-36 Prospect Street, Hull HU3 8PX } \\
\text { St James University Hospital, Beckett Street, Leeds LS9 7TF } \\
\text { Windhill Green Medical Practice, } 2 \text { Thackley Old Road, Shipley BD18 1QB } \\
\text { Department of Sexual Health, Royal Bolton Hospital, Minerva Road, Farnworth, Bolton BL4 0JR } \\
\text { Gynaecology Department, Countess of Chester Hospital, The Countess of Chester Health Park, Chester CH2 1UL } \\
\text { Saltergate Health Centre, Chesterfield S40 1SX } \\
\text { Clinical, Training and Administrative Headquarters, St Peters Health Centre, Sparkenhoe Street, Leicester LE2 0TA } \\
\text { St Patrick's Centre for Community Health, Frank Street, Highgate, Birmingham B12 0YA } \\
\text { Kettering General Hospital, Rothwell Road, Kettering NN16 8UZ } \\
\text { Sexual Health Clinic, Pond Street, Carmarthen SA31 1RT } \\
\text { Llanyrafon House, Llanfrechfa Grange Hospital, Cwmbran, Torfaen NP44 8YN } \\
\text { Central Hill Clinic, Tower Hill, Bristol BS2 OJD } \\
\text { The Quay to Health, The Quays Swimming and Diving Complex, } 27 \text { Harbour Parade, Southampton SO15 1BA } \\
\text { 26 Old Dover Road, Canterbury, Kent CT1 3JH } \\
\text { Department of Contraception and Sexual Health, Maple House, Canada Avenue, Redhill RH1 5RH } \\
\text { Garden Clinic, 140 Windsor Road, Slough SL1 2JB } \\
\text { Market Street Health Centre, Market Street, Woolwich SE18 6QF } \\
\text { Streatham Hill Sexual Health Centre, 41a-C Streatham Hill, London SW2 4TP } \\
\text { Raymede Clinic, St Charles Hospital, Exmoor Street, Kensington, London W10 6DZ } \\
\text { Margaret Pyke Centre, 73 Charlotte Street, London W1T 4PL } \\
\text { Homerton University Hospital NHS Foundation Trust, Homerton Row, London E9 6SR }\end{array}$ \\
\hline
\end{tabular}

The referral centres have been informed that patients will be referred by letter, and indeed this is their preferred method of communication. The list of referral centres is subject to change, and therefore doctors should contact Organon Laboratories for details of their nearest centre.

secret'; thus few clinicians or service managers have been able to submit business plans, resulting in regrettable delays to service development. This situation needs to be addressed, and as soon as possible.

\section{Statements on funding and competing interests}

Funding The author has received honoraria and expenses for attendance at advisory boards, lectures and sponsored symposia for Organon Laboratories (part of the Schering-Plough Corporation).

Competing interests None identified.

\section{References}

1 Chandy C. Implant removal by modifying access (Letter). J Fam Plann Reprod Health Care 2008; 34: 273.

2 Bennett A. Norplant removal forceps (Letter). J Fam Plann Reprod Health Care 2008; 34: 273-274.

3 Mansour D, Walling M. Reply: Norplant removal forceps (Letter). J Fam Plann Reprod Health Care 2008; 34: 274.

4 Abeysundera M. Localisation of non-palpable implants (Letter). J Fam Plann Reprod Health Care 2008; 34: 136.

5 Mansour D, Walling M, Glenn D, Egarter C, Graesslin O, Herbst J, et al. Removal of non-palpable etonogestrel implants. J Fam Plann Reprod Health Care 2008; 34: 89-91.
6 Mansour D, Fraser IS, Walling M, Glenn D, Graesslin O, Egarter $\mathrm{C}$, et al. Methods of accurate localisation of nonpalpable subdermal contraceptive implants. J Fam Plann Reprod Health Care 2008; 34: 9-12.

7 Singh M, Mansour D, Richardson D. Location and removal of non-palpable Implanon ${ }^{\circledR}$ implants with the aid of ultrasound guidance. J Fam Plann Reprod Health Care 2006; 32: 153-156.

8 Organon Laboratories Ltd. Implanon $68 \mathrm{mg}$ implant for subdermal use (updated 14 July 2008). http://emc. medicines. org.uk/emc/assets/c/html/DisplayDoc.asp?DocumentID=5382 [Accessed 1 November 2008].

9 Webb AMC. Why go to Tiger Country? A report of two cases of Implanon ${ }^{\circledR}$ removal. J Fam Plann Reprod Health Care 2006; 32: 193-194.

10 Organon Laboratories Ltd. Guidance to the revised SMPC for Implanon (Leaflet). September 2008

11 National Collaborating Centre for Women's and Children's Health. Commissioned by the National Institute for Health and Clinical Excellence. Long-Acting Reversible Contraception (Guideline 30). http://www.nice.org.uk/CG030 [Accessed 1 November 2008]

12 Department of Health. Statement on Contraception and Teenage Pregnancy. 24 June 2008. http://www.dh.gov.uk/en/ Publichealth/Healthimprovement/Sexualhealth/DH_085686 [Accessed 1 November 2008].

\section{PEER REVIEWERS/JOURNAL REVIEW WRITERS WANTED}

\section{PEER REVIEWERS}

If you have a special interest in one or more of the topics covered by the Journal and have some time available to peer review occasional papers in your own area(s) of expertise then perhaps you might be interested in joining the Journal's team of peer reviewers? In common with the majority of other academic journals, peer reviewers offer their services on a voluntary basis; however, if you are a member of the Faculty of Sexual and Reproductive Healthcare then each completed review counts for two (2) CME points.

\section{JOURNAL REVIEW WRITERS}

The Journal regularly reviews articles from related publications (see page 52) and is looking to recruit more volunteers to compile these short reviews. For further information and/or to offer your services (at most once or twice a year) please e-mail your contact details to the Journal Editorial Office together with a note of any special interests and/or expertise to assist us in allocating relevant articles to individual reviewers.

For further information on either of these roles please contact the Journal Editorial Office at journal@fsrh.org. 